\title{
Distribution of fluorine between phlogopite, K-richterite, apatite and lamproitic melt in high-pressure experiments
}

\author{
ISRA S EZAD AND STEPHEN F. FOLEY
}

Macquarie University

Presenting Author: isra.ezad@mq.edu.au

Phlogopite (PHL), amphibole (KR) and apatite (AP) are the principal halogen-bearing minerals in hydrous pyroxenites and glimmerites, which occur as xenoliths in kimberlites, ultramafic lamprophyres and related alkaline rocks, and represent probable source components for the host magmas. The same minerals frequently occur in the fractionation series of alkaline igneous rocks, and are important in controlling the evolution of halogen contents in melts. However, despite the crescendo in interest in halogens in alkaline rocks, relatively few data are available for the mineral/melt partitioning of halogens in experiments at known temperature and pressure for magma sources.

Here, we present partitioning data for fluorine in high-pressure experiments for several mineral/melt pairs: (1) for PHL, KR and AP during the partial melting of hydrous pyroxenites at 1.5 and 5 $\mathrm{GPa}$; (2) for PHL in leucite and olivine lamproites at 0.5-5.5 GPa $[1,2]$; and (3) for PHL in an $\mathrm{H}_{2} \mathrm{O}$-free, fluorine-bearing simple system at $2.8 \mathrm{GPa}$. In the hydrous pyroxenite melting experiments, $\mathrm{D}_{\mathrm{PHL} / \mathrm{L}}$ ranges from 0.46 to 3.43 , averaging 1.58 , with only 6 of 28 measurements $>1$, including all at $5 \mathrm{GPa}$. Fluorine is compatible in all three hydrous minerals, with partition coefficients decreasing in the order $\mathrm{D}_{\mathrm{AP} / \mathrm{L}}(2.21)>$ $\mathrm{D}_{\mathrm{PHL} / \mathrm{L}}(1.58)>\mathrm{D}_{\mathrm{KR} / \mathrm{L}}$ (1.36). Apatite coexisting with PHL or KR takes at least twice as much fluorine at $1.5 \mathrm{GPa}\left(\mathrm{D}_{\mathrm{PHL} / \mathrm{AP}}=0.49\right.$, $\left.\mathrm{D}_{\mathrm{KR} / \mathrm{AP}}=0.37\right)$. The lamproite experiments were equilibrated in reducing conditions with low $\mathrm{CH}_{4} / \mathrm{H}_{2} \mathrm{O}$, but $\mathrm{PHL}$ shows marked compositional variations as a function of oxygen fugacity, with $\mathrm{F}$ contents highest where $\mathrm{BaO}$ and $\mathrm{Al}_{2} \mathrm{O}_{3}$ are lowest at low $\mathrm{fO}_{2}[1]$. Fluorine (up to $1.08 \mathrm{wt} \%$ ) shows a strong negative correlation with $\mathrm{Al}_{2} \mathrm{O}_{3}$ and $\mathrm{F}$ is higher in olivine lamproite $\mathrm{PHL}$, in keeping with the higher $\mathrm{F}$ contents of the bulk rock $(0.53 \mathrm{vs} .0 .33 \mathrm{wt} \%)$. In the kalsilite-forsterite-quartz simple system experiments, PHL has $5.2-7.5 \mathrm{wt} \% \mathrm{~F}$, with $14-43 \%$ of $\mathrm{F}$ sites apparently occupied by oxygen in these nominally $\mathrm{H}$-free experiments.

[1] Foley, S.F. (1989) Eur. J. Min 1, 411-426

[2] Foley, S.F. (1993) Geochim. Cosmichim. Acta 57, 483-489

[3] Foley, S.F., Taylor, W.R., Green, D.H. (1986) Contrib. Mineral. Petrol. 93, 46-55 